\title{
Investiguem i ens comuniquem científicament: una proposta de centre com a dinamització de la Competència Científica
}

Joan Antoni Álvarez (jalvare9@xtec.cat) INS de Vilanova del Vallès Jordi Domènech-Casal (jdomen44@xtec.cat) INS de Granollers i Grup LIEC, Departament de Didàctica de les Matemàtiques i les Ciències, Universitat Autònoma de Barcelona (UAB).

Anna Garrote (agarrote@xtec.cat) INS de la Roca del Vallès Jesús Gasco (jesusgasco@gmail.com) INS de Granollers Carlos Oliveros (colivero@xtec.cat) INS de Vilanova del Vallès Lluís Rodríguez (Irodrig8@xtec.cat) INS de Vilanova del Vallès

El desenvolupament de la competència científica implica la participació en primera persona en activitats d'investigació i comunicació científica. Es presenta una experiència de centre duta a terme els cursos acadèmics 2013-2014 i 2014-2015 en la que, en el marc de la Setmana de la Ciència, han participat els alumnes de tots els cursos i el professorat de ciències de l'Institut de Secundària INS Vilanova. Els alumnes han investigat i comunicat a companys d'altres cursos els seus resultats en diversos formats científics. L'experiència s'ha valorat com a molt positiva per a l'interès de l'alumnat en la ciència, el desenvolupament d'habilitats científiques i la difusió de diverses tipologies d'activitats competencials.

Paraules clau: indagació, comunicació científica, context, competència científica

The development of the scientific competence implies participating in first person in scientific communications and investigation activities. Here, we present an experience developed during 2013-2014 and 2014-2015 academic courses in the The Science Week in which science teachers and students from all courses from the high school INS Vilanova have participated. Students have investigated and communicated to mates from other courses their results in different scientific formats. The experience has been valued very positively due to the increase interest of students in science, the development of scientific abilities and the diffusion of different typologies of scientific activities.

Keywords: inquiry, scientific communication, context, scientific competence.

\section{INTRODUCCIÓ}

Els nous marcs metodològics d'ensenyament de les ciències $(\mathrm{ECBI}$, ciència en context, ciència i societat) posen èmfasi en que la competència científica s'aconsegueix quan s'és capaç de transferir els coneixements a nous contexts i de comunicar-los científicament (Hodson, 1994). Alguns informes -com l'informe Rocard- i diversos experts insisteixen en que aquest apropament de la ciència a l'alumnat s'ha de dur a terme promovent metodologies d'investigació a l'aula (Rocard et al, 2006, Bybee, 2006).

El treball a l'aula de ciències hauria, doncs, de girar al voltant de la proposta de preguntes investigables en les que els alumnes juguessin un paper actiu desenvolupant habilitats científiques com fer hipòtesis, dissenyar experiments, extreure conclusions de dades i comunicar científicament (Caamaño, 2012). Diversos autors defensen que l'orientació de 
les activitats científiques investigadores a la comunicació és crucial, per dues raons: 1) implica la modelització dels fenòmens observats, aspecte clau en les ciències (Simarro et al, 2013), i 2) suposa una aportació per al desenvolupament de les habilitats cognitivo-lingüístiques associades al raonament científic (descriure, justificar, argumentar,...), que es poden promoure mitjançant l'ús de bastides lingüístiques que ajudin a comunicar en gèneres discursius i tipologies textuals científics (Sanmartí, 1999 i 2008, Domènech-Casal, 2013).

La celebració de congressos científics escolars és un format comunicatiu molt útil per a empoderar els alumnes en rols investigadors de "constructors de coneixement" i promoure dinàmiques de comunicació formal/informal escrita i oral. Les diverses experiències que es poden trobar solen anar dirigides a que els alumnes d'un grup-classe es presenten entre si o a convidats externs al centre les seves investigacions en formats de comunicació oral o pòster científic (Domènech-Casal, 2014, Hinojosa, 2014).

En el marc de la Setmana de la Ciència, a l'INS Vilanova del Vallès hem dut a terme els dos darrers cursos acadèmics (2013-2014 i 2014-2015) una iniciativa en aquesta línia que, enlloc de centrar-se a un o dos grups-classe ha implicat tot l'institut sencer al voltant de la investigació i comunicació científica amb l'objectiu de desenvolupar activitats científiques competencials. Descrivim a continuació l'experiència $i$ algunes de les investigacions realitzades amb els alumnes i les nostres reflexions sobre aquesta iniciativa que valorem molt positivament i pretenem consolidar al centre.

\section{DESCRIPCIÓ DE L’EXPERIÈNCIA}

L'Institut de Vilanova del Vallès està format per més de 300 alumnes i més de 50 professors i s'hi ofereixen dels nivells des de $1 r$ d' ESO a $2 n$ Batxillerat. A l'inici del curs 2013-2014 es va plantejar al Departament de Ciències de l'institut la voluntat de fer alguna activitat que promogués l'activitat científica dels alumnes com a celebració de la Setmana de la Ciència. El professorat del Departament de Ciències del centre va acordar que en tots els grups-classe es proposaria i es duria a terme una investigació científica relacionada amb el currículum de matèries científiques d'aquell nivell, i que els alumnes presentarien les seves investigacions en un format científic, que inclogués els apartats d'Introducció, Material i Mètodes, Resultats i Conclusions.
Sense alterar l'horari convencional, i aprofitant les hores en què coincidien classes de ciències a diferents nivells es va aconseguir que, enlloc de presentar la investigació al professorat o entre els alumnes del grup, cada grup d'alumnes presentés la seva investigació a alumnes d'altres nivells [1]. D'aquesta manera, al llarg d'una setmana els alumnes de $4 \mathrm{t}$ d'ESO presentaren les seves investigacions a alumnes de $2 n$ d'ESO (i viceversa), alumnes de $3 r$ d'ESO les presentaren a alumnes de $1 \mathrm{r}$ de Batxillerat,... Durant la segona mitja hora, es feia a la inversa. Aquesta va resultar ser una dinàmica de coneixement molt particular, que s'ha repetit el curs següent (2014-2015). Tot seguit descrivim algunes de les investigacions realitzades pels alumnes i discutim l'aportació que ha suposat aquesta dinàmica al centre i l'educació científica de l'alumnat.

\section{1) Els gens s'hereten, els memes [2] es transmeten. Heredity Id.}

Aquesta investigació va ser conduïda per alumnes de la matèria de Biologia i Geologia de 4t d'ESO i presentada a alumnes de $1 \mathrm{r}$ i $2 \mathrm{n}$ d'ESO. En sintonia amb el currículum de la matèria, es va proposar als alumnes que, en equips de tres, intentessin identificar els patrons d'herència genètica d'un caràcter qualitatiu observable de la seva elecció (forma dels lòbuls de l'orella, longitud relativa dels dits,...) a partir de la construcció d'arbres genealògics amb dades de quatre famílies reals del seu entorn. Per a fer l'activitat es van proporcionar als alumnes diversos recursos que es van agrupar en forma de la Webquest Heredity ld [3], on es poden trobar els materials de l'activitat, catalogada a I'Aplicació de Recobriment Curricular (ARC) [4].

Els alumnes van recollir les diverses dades en forma de pedigrees, analitzant la consistència/no consistència dels diferents models d'herència explicats a l'aula (autosòmica recessiva/dominant i lligada al sexe recessiva/dominant). Es va proporcionar als alumnes una bastida per a la realització d'un pòster científic que identifica els diferents apartats del pòster, les funcions que juguen en la comunicació (descriure, argumentar, exposar...) i iniciadors de frase i connectors lingüístics de recolzament [5]. Els alumnes van defensar els seus pòsters en una sessió de pòsters científics, on els alumnes de $1 \mathrm{r}$ i $2 n$ d'ESO deambularen i preguntaren activament. 


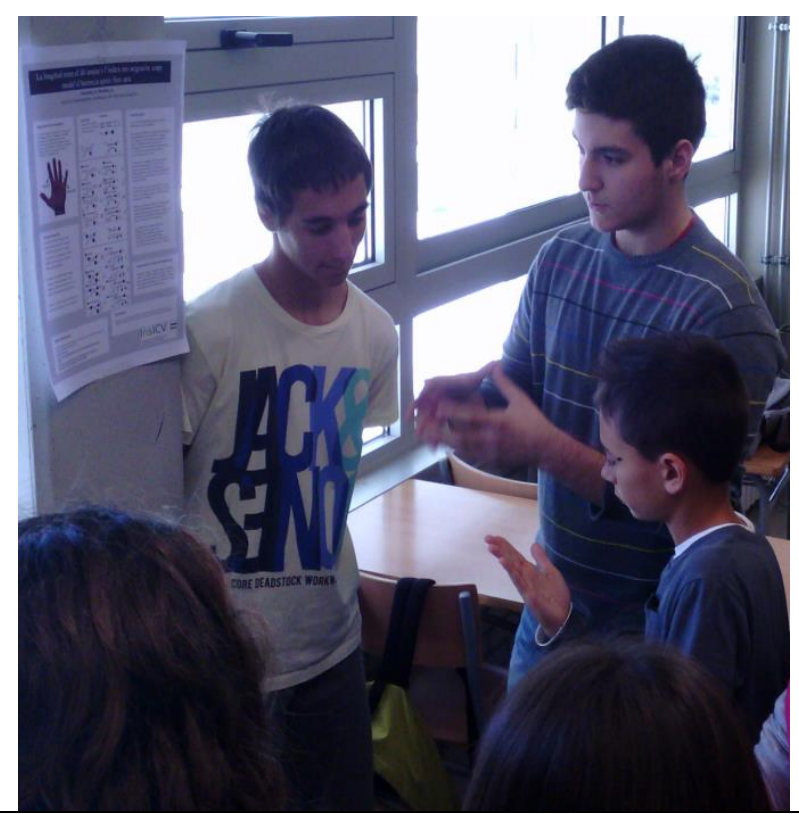

Figura 1: Alumnes de 4t d'ESO explicant a alumnes de $1 \mathrm{r}$ d' ESO les seves investigacions sobre l'herència de la llargada dels dits de la mà. L'intercanvi entre alumnes de diferents edats promou que es relacionin en el marc del coneixement i els rols científics.

Aquest treball inicial amb el pòster ha estat útil per a definir les parts de què consta una investigació i la seva correspondència amb diferents tipus de raonament científic. S'ha observat en diversos casos que durant l'explicació s'establien entre els alumnes discussions que han posat en evidència i corregit concepcions errònies sobre els conceptes i estratègies utilitzats entre iguals sense que fos necessària la intervenció del professor.

L'activitat de determinar els patrons d'herència de caràcters heretables en les famílies és una activitat clàssica, amb un elevat potencial per a desenvolupar-ne variants (Auteri, 2015), però que cal tractar amb cura en relació a aspectes de privacitat [6].

\section{2) Cristal-litzant coneixement cientí- fic}

Amb els alumnes de $2 n$ d'ESO de Ciències Naturals, l'activitat escollida va ser la cristal-lització, ja que durant el primer quadrimestre del curs treballem la geologia, i va ser presentada a alumnes de $2 n$ de Batxillerat.

Vam treballar la cristal-lització de la sal comuna $(\mathrm{NaCl})$, i el procediment que els alumnes havien de seguir era molt senzill: es tractava de dissoldre la màxima quantitat possible de sal comuna en aigua calenta i un cop tenien la dissolució sobresaturada, havien de filtrar-la , posar-li un nucli de cristal-lització -que en el nostre cas era un clip metàl-lic-, el qual dipositàvem a l'interior de la dissolució ajudant-nos d'un fil de llana i un llapis i finalment havíem de deixar en repòs la dissolució. Vam observar amb la lupa els cristalls per tal que els alumnes poguessin analitzar la geometria dels cristalls obtinguts, les diferents mides, el color, la textura i qualsevol altra característica que poguessin observar.
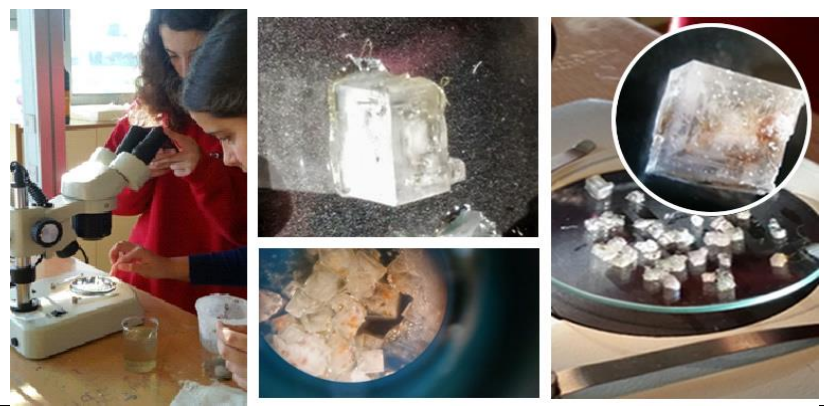

Figura 2: Anàlisi dels cristalls. Durant tres setmanes els alumnes anaven observant els canvis que es produïen, feien fotografies i anotacions, per poder elaborar el document final que presentarien als seus companys. Aquest procediment el fèiem en una hora de laboratori, els alumnes havien de reconèixer perfectament el material utilitzat i la seva aplicació en el procés, havien d'entendre el procediment aplicat, sabent quin era l'objectiu de cada acció.

Amb totes les dades obtingudes durant aquest període de temps, els alumnes havien de fer una exposició oral del contingut i resultats de la investigació realitzada, elaborant un material gràfic de tot el procés [7]: una Introducció (on els alumnes havien de parlar del procés de cristal-lització, què és i quan s'aplica) un Material i Mètodes, on havien d'enumerar el material utilitzat, i el seu ús concret en aquesta pràctica i procediments usats), i uns Resultats i Conclusions. Als Resultats, els alumnes havien de descriure l'evolució en el desenvolupament dels cristalls, on s'havien format preferentment i comentar els resultats finals obtinguts, i a les Conclusions els alumnes havien de raonar diversos aspectes:

- A què es deuen les diferents mides dels cristalls obtinguts?

- Per què es formen en un lloc o un altre? On s'han format els més grossos?

- Per què tenen una determinada geometria?

- Per què apareixen taques als cristalls? [8]

En alguns grups de treball l'obtenció de cristalls havia sigut mínima i en aquest últim apartat els alumnes havien de raonar perquè no havien obtingut 
gaires cristalls i fer una recerca sobre quins haurien sigut els resultats en cas de que el procés s'hagués desenvolupat correctament (tipus de cristalls que forma el clorur de sodi, mides, geometria, color...). L'experiència ha estat molt positiva, els alumnes en general han tingut inquietud i interès durant el procés i a més ha sigut un repte i una experiència molt enriquidora preparar i exposar els resultats, no pels seus companys de classe com fem habitualment, sinó per alumnes de batxillerat, que tot sigui dit, van valorar molt positivament la feina realitzada pels alumnes de $2 n$ d'ESO.

\section{3) Nosaltres ensenyem, nosaltres aprenem: investigant la fotosíntesi}

En aquesta experiència, 10 alumnes de $2 n$ de batxillerat preparen i condueixen per a 25 alumnes de $2 n$ d'ESO dues pràctiques de laboratori escolars sobre la fotosíntesi, un tema present en el currículum d'ambdós cursos. Els alumnes de batxillerat actuaren de professors, dissenyant, construint i avaluant dues activitats didàctiques per als alumnes de $2 n$ d'ESO:

- Pràctica 1: una activitat escrita on a partir de diverses dades es demana als alumnes de $2 n$ d'ESO valorar si s'ha produït o no fotosíntesi a partir de la producció o no de gas, en dues condicions d'estudi: en presència de llum o en absència.

- Pràctica 2: una pràctica de laboratori d'extracció de pigments fotosintètics en fulles d'espinacs.

L'alumnat de $2 \mathrm{n}$ de batxillerat ha preparat les activitats en equips de 2 o 3 alumnes, amb els que ha conduït l'activitat durant uns 25 minuts al laboratori. Una vegada feta l'activitat han fet una correcció de la mateixa i s'ha fet arribar els resultats (avaluantlos) a l'alumnat de $2 \mathrm{n}$ d'ESO. El guió de l'activitat pràctica d'extracció de pigments de fulles d'espinac ha estat un resultat valorat molt positivament $i$ es conserva per a properes edicions [9].

La valoració com a professor de la matèria de biologia de $2 n$ de batxillerat ha estat molt positiva en tant que s'ha pogut veure com els alumnes han sabut desenvolupar-se bé en el laboratori i han estat uns bons guies en aquest, així com la destresa que han tingut en elaborar un material avaluable per l'alumnat de $2 \mathrm{n}$ d'ESO. L'alumnat de $2 \mathrm{n}$ de batxillerat també ha manifestat haver estat molt a gust fent aquesta activitat.

\section{4) Classificar éssers vius, des-jerar- quitzar alumnes}

En aquesta activitat es proposà a alumnes de $\mathrm{Ci}$ ències Naturals de $1 r$ d'ESO que preparessin una una activitat per als alumnes de batxillerat i $3 r$ d'ESO. Els alumnes de $1 \mathrm{r}$ d'ESO van adaptar una activitat didàctica que havien dut a terme a l'assignatura (basada en la classificació dels éssers vius i la construcció de claus dicotòmiques [10]) com a joctaller per a alumnes de batxillerat. En el joc- taller es demanava als alumnes de batxillerat que desenvolupessin una clau dicotòmica a partir d'imatges de diversos éssers vius. Es van formar grups mixtes, on els alumnes de $1 \mathrm{r}$ d'ESO van entregar un sobre tancat al membres del seu grup de cursos superiors on hi havia una col-lecció de fotografies retallades individualment (al voltant de 14) d'éssers vius de diferents regnes. El alumnes de $1 \mathrm{r}$ d'ESO els van explicar que havien de fer el seu propi arbre de classificació usant criteris de classificació que permetin separar-los dicotòmicament.
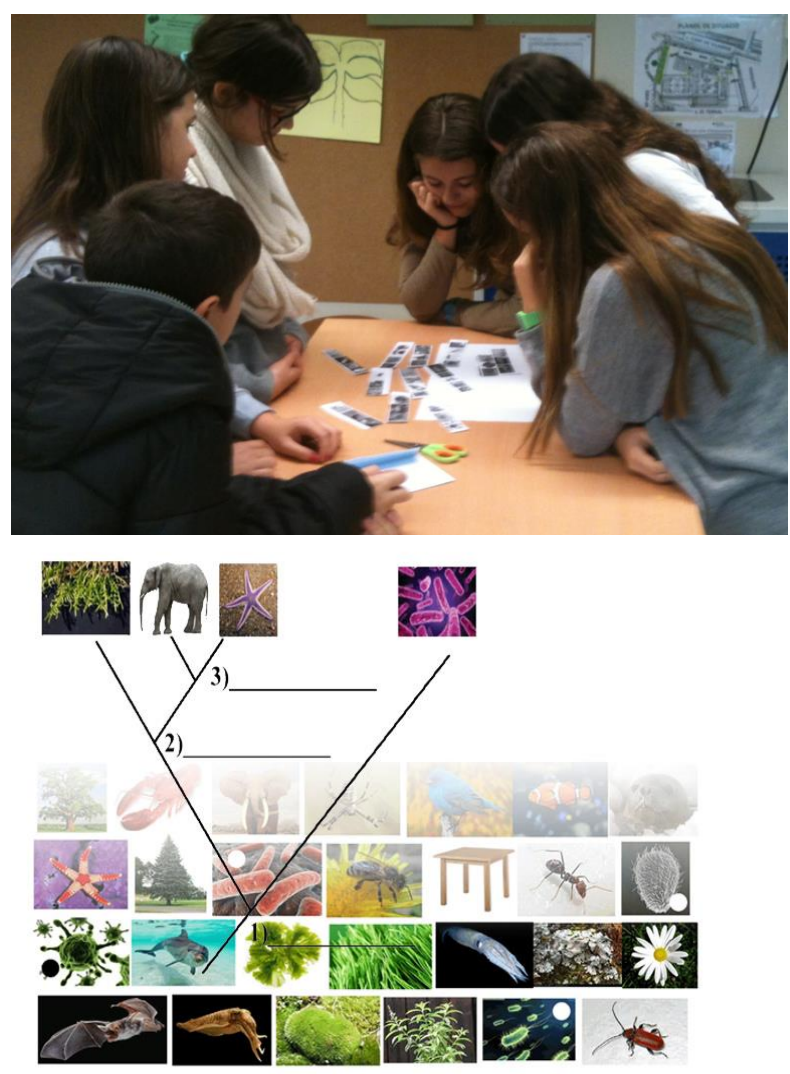

Figura 3: Alumnes de 1r d' ESO proposant a alumnes de $3 r$ d'ESO el repte de resoldre la classificació de diversos éssers vius. A més d'éssers vius es va incloure alguna fotografia d'objectes no-vius, com ara taules de fusta. Com a suport, se'ls va entregar un full DIN-A3 amb el dibuix de l'inici d'un arbre de classificació mut composat per una arrel i dues branques. 
Els estudiants de batxillerat van començar a separar les imatges, en general van començar a separar per regnes, els animals a una banda, els vegetals a l'altre, etc. Però en cap cas van tenir clar ni van aplicar en un principi la separació del éssers vius per tipus d'alimentació, sistema de reproducció, per estructura cel-lular o per complexitat dels teixits que els formen. Aleshores, els alumnes de 1r ESO van interactuar amb ells indicant-los els criteris de classificació que usaven a classe, acompanyant-los a recordar conceptes que, en teoria haurien de tenir assimilats fa anys. Els alumnes de $1 \mathrm{r}$ d'ESO van quedar una mica sorpresos de que els alumnes de batxillerat, més grans que ells i amb més anys d'estudi no sabessin utilitzar conceptes per ells tan bàsics; tot i això, els alumnes de 1r d'ESO van mostrar sempre actitud de respecte cap als més grans i els van explicar dintre d'un ambient molt participatiu aquells conceptes que havien oblidat. El estudiant de batxillerat van reaccionar rient d'ells mateixos i escoltant als alumnes de $1 \mathrm{r}$ d'ESO quan parlaven de vegades amb timidesa. Al final, els estudiant de batxillerat van aconseguir acabar amb èxit el seu l'arbre de classificació dicotòmica.

\section{5) Okupem espais comuns... de cièn- cia}

Es va proposar els alumnes de tercer d'ESO de comunicar investigacions al voltant de diverses temàtiques del currículum de les Ciències Naturals, fent una exposició de ciència un espai comú de l'institut, el hall o entrada. Els alumnes van fer diverses investigacions i les van presentar en forma de pòster científic. Entre les investigacions proposades:

- Quina part de la pell és més sensible?

- Com afecta l'exercici físic a l'activitat cardíaca i respiratòria?

- Quin és el temps de reacció a un estímul?

- Com estan distribuïdes les papil-les gustatives?

És important destacar que aquestes preguntes s'ajusten al que s'ha descrit com a bons iniciadors d'investigacions, ja que s'ajusten al model "Què passa si...?" "Fa alguna diferència si...?" que permet iniciar bones activitats d'investigació. Els alumnes realitzaren les investigacions per parelles i es van agrupar en equips de quatre per a dur a terme el pòster, el que suposa un tasca afegida de comunicació, selecció de dades i generació de consens. Alguns alumnes van presentar també pòsters al voltant de pràctiques més descriptives d'observació de diferents teixits i òrgans animals (mucosa bucal, cor o pulmó de xai,...).
D'acord amb aquests diferents enfocs de pràctiques (investigadores o demostratives), es van proposar als alumnes també diferents models de pòster, adequats a cada tipologia. Els pòsters van formar part de les activitats avaluables a la matèria i es van exposar a l'espai comú de l'entrada de l'institut, constituint una oportunitat de que alumnes de cursos inferiors (1r i $2 n$ d'ESO) creessin expectatives de pràctiques o investigacions que es farien en cursos posteriors.

\section{6) Cuinant interès per la ciència amb química aplicada}

En aquesta experiència, 10 alumnes de $1 r$ de batxillerat, dins de la matèria de química, han dut a terme un taller de divulgació sobre química a la cuina per a quinze alumnes de $1 r$ d'ESO. L'objectiu de l'activitat és acostar la química als alumnes de $1 r$ de l'ESO, a partir d'experiències quotidianes com és la cuina, per una banda, i introduir i treballar conceptes relacionats amb les reaccions químiques que es donen en el currículum de $1 \mathrm{r}$ de batxillerat. L'activitat es realitza en dues sessions. A la primera es prepara el taller (compost de dos experiments) amb els alumnes de de batxillerat, explicant els conceptes que es treballen per tal que ho puguin transmetre després als alumnes de $1 r$ d'ESO, i fent la pràctica per a observar els resultats. A la segona els alumnes de batxillerat duen a terme el taller als alumnes de la ESO.

En el primer experiment es treballen les reaccions àcid-base i els indicadors a partir de de fer un ou ferrat de color verd gràcies a la propietat de l'extracte de col llombarda que actua com a indicador. La clara de l'ou és lleugerament alcalina de manera que l'extracte de col pren una tonalitat verdosa. Cal barrejar una mica de l'extracte amb la clara de l'ou (prèviament s'ha separat del rovell) i afegir la mescla a la paella calenta i fer l'ou ferrat. El resultat: un espectacular ou ferrat de color verd. Es pot acompanyar amb un suc de llimona de color vermell/rosat, ja que l'extracte pren aquest color en medi àcid. Les eines necessàries per fer l'activitat són els estris de cuina habituals per fer un ou a casa i un bunsen o fogonet de càmping.

En el segon experiment es treballa una reacció de doble substitució amb alginat de sodi i l'ió de calci, la famosa esferificació. Es tracta de fer una solució d'alginat sòdic en aigua $(5 \mathrm{~g} / \mathrm{L})$ i afegir petites porcions de iogurt (que conté calci) dins de la solució. La reacció entre el calci i l'alginat dona alginat de calci que presenta una textura gelatinosa, formant unes boles sòlides ( textura de gel) per fora 
amb iogurt líquid per dins molt curioses. El material necessari és molt senzill, cal una balança per pesar les quantitats d'alginat, una batedora, per homogeneïtzar la mescla perquè costa una mica de dissoldre, un recipient per posar la mescla i culleres per posar i recollir el iogurt esferificat.

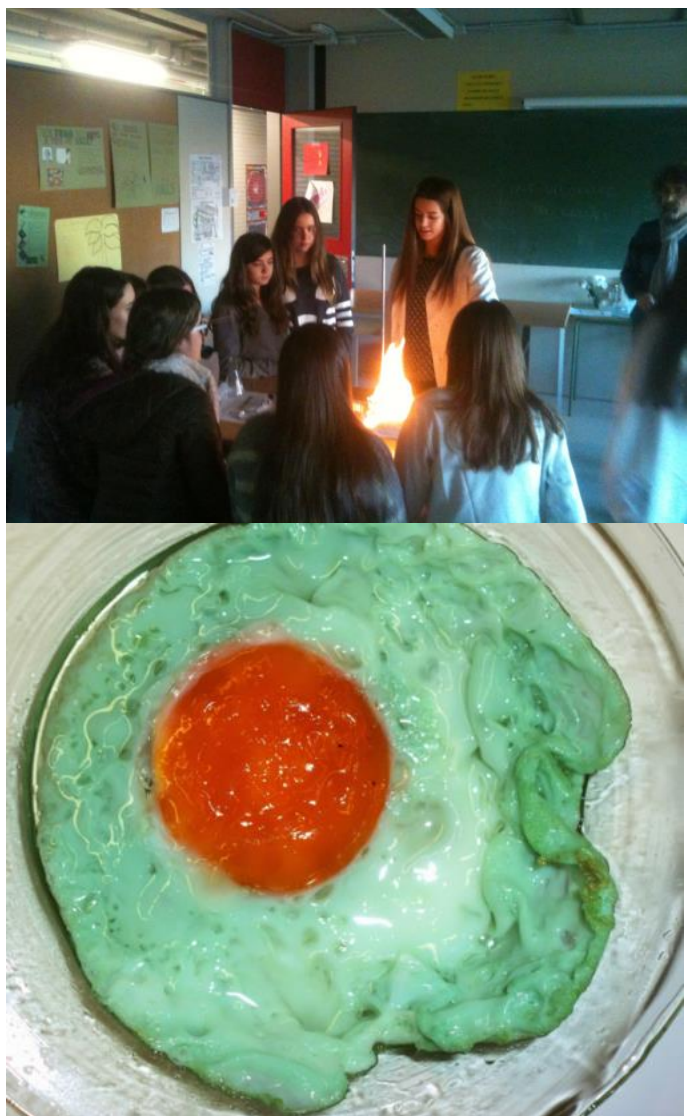

Figura 4: .El canvi de rol dels alumnes i el context sorprenent són elements importants en aquest tipus d'activitats: (a la dreta) imatge d'una altra activitat similar realitzada al centre seguint la mateixa estratègia sobre màgia i cuina. (a l'esquerra) Un ou verd degut a l'indicador de la col llombarda. Les possibilitats de la cuina per a generar situacions sorprenents o, a priori, incomprensibles, són una oportunitat per a partir del conflicte cognitiu en l'aprenentatge de les ciències. Imatge modificada del blog PepQuímic [11], on el lector trobarà altres experiments interessants.Aportacions de l'activitat a la Competència Científica

Alumnat i professorat ha valorat el taller com a molt interessant, per diverses raons:

- El tema escollit és força atractiu, la barreja d'aspectes quotidians que coneixem tots, com fer un ou ferrat, amb modificacions sorprenents, crida l'atenció.
- El canvi de rol, els alumnes fan de professors, genera una responsabilitat que resulta molt positiva i unes expectatives pels alumnes que reben l'explicació molt engrescadores.

- Aquesta responsabilitat d'haver d'explicar les reaccions a altres alumnes, genera la necessitat d'entendre el que s'està fent de manera que cal una apropiació més elevada dels conceptes teòrics.

\section{DISCUSSIÓ I CONCLUSIONS}

Per a valorar l'activitat s'han recollit de manera no sistemàtica en discussions conjuntes les valoracions dels alumnes durant i en dies posteriors a l'activitat i s'ha fet una valoració de l'activitat en el marc de les reunions del Departament de Ciències del centre docent. L'alumnat ha valorat molt positivament l'activitat, i han demanat fer-la de nou, qualificant-la de "divertida", "diferent" i "emocionant". En casos d'alumnes amb germans al centre, alguns alumnes han comentat amb els professors les recerques que els seus germans estaven duent a terme, el que indica que els alumnes han comentat a casa la recerca que feien com a quelcom significatiu. En la sessió sobre la classificació dels éssers vius, s'ha dut a terme a més una enquesta de valoració, en la que tots els enquestats afirmen que han entès els continguts de l'activitat i la valoren unànimement amb la puntuació màxima, de 10 . En alguns casos l'activitat s'ha incorporat a l'avaluació de la matèria, i en d'altres no. Fins i tot quan s'ha dit que l'activitat no qualificava de cap manera per a la nota de l'assignatura, els alumnes s'han molt seriosament la seva presentació.

L'activitat ha generat diversos formats de comunicació científica (tallers de divulgació, sessions de pòsters científics, jocs-taller científics, pràctiques de laboratori escolars, produccions audiovisuals, exposicions orals), quelcom especialment important perquè aquests són formats específics del llenguatge científic, i per tant, comparteixen elements clau del raonament científic: la importància de mostrar evidències, el raonament com a mitjà per a extreure conclusions de les evidències... Això ha significat una oportunitat perquè alumnat i professorat presenciés diversos formats d'activitats rics per a la promoció de la competència científica. Les activitats han també compaginat diversos tipus de comunicació (escrita, oral, audiovisual), facilitant la participació de l'alumnat i la interacció entre alumnes de diferents cursos usant els diferents tipus de comunicació, un element important per a la formació en competència comunicativa de l'alumnat (Canale, 1983), 
però també en la construcció del coneixement científic, ja que, com diversos autors defensen, saber explicar la ciència és un element clau per a saber-la (Lemke, 1997, Hernández i Hernández, 2011, Martín, 2013).

El fet que aquesta comunicació partís de conflictes cognitius o investigacions (com s'hereta un caràcter concret, quina part de la pell és més sensible, quins factors afecten la cristal/lització...) és també un element important, ja que en ocasions l'alumnat té dificultats per a connectar amb els coneixements científics per la seva presentació com un corpus monolític descriptiu. Les activitats d'investigació i contextualització en problemes concrets i modelització a partir d'evidències han permès connectar l'alumnat amb els conceptes i models de la ciència, tal com descriuen altres autors (Pozo i Gómez, 2010, Bybee, 2006, Sanmartí et al, 2011, Simarro et al, 2013).

Els diferents passos de les investigacions (Introducció, Material i Mètodes, Resultats, Conclusions) permeten treballar habilitats científiques bàsiques, pel que l'activitat suposa una via per a treballar-les de manera específica, vinculada al currículum i connectada al les demandes de competència científica que es fan des d'organismes internacionals. De fet, l'activitat incideix en els tres dominis de les proves PISA 2015 (Garrido i Simarro, 2014):

- Explicar fenòmens científicament.

- Avaluar i dissenyar una indagació científica.

- Interpretar dades científicament.

Durant l'activitat els alumnes han expressat repetidament les dificultats que tenien per a explicar conceptes complexos (gen, al $/$ el, cristall, criteri de classificació) a alumnes d'altres cursos, i han recorregut a metàfores, paràfrasis o modelitzacions per aconseguir comunicar la seva recerca ("el pare dóna un color i la mare en dóna un altre", "la clorofil•la puja", "és el que tenen de diferent dos éssers vius",...), el que suposa una tasca de re-contextualització que exercita la capacitat de transferència dels conceptes i models científics i significa una oportunitat per a detectar concepcions errònies.

En resum creiem que la proposta suposa una via d'acció útil per a:

- Compartir entre alumnes i professors tipologies d'activitats didàctiques.

- Construir una visió compartida dels aspectes i elements comunicatius de l'ensenyament de les ciències (lèxic, modelització, argumentació....).
- Generar interès per la ciència entre l'alumnat.

- Desenvolupar habilitats científiques entre l'alumnat (disseny d'experiments, registre i anàlisi de dades, comunicació de conclusions...).

\section{Una recepta amb vocació de continu- ïtat}

L'activitat ha implicat l'institut sencer i s'ha dut a terme durant dos cursos acadèmics (2013-2014 i 2014-2015) al llarg de d'una setmana cada curs, sense implicar aturada de les classes, simplement compaginant les hores de classe de ciències de les que ja es disposava. En paral-lel, s'ha dut a terme un concurs de fotografia científica obert a la participació de professorat, alumnat i famílies. Des d'un punt de vista de popularització de la ciència, creiem especialment interessant el fet que alumnes de cursos diferents que habitualment no interactuen ho hagin fet a través del llenguatge i el coneixement científic. Pensem que és un tipus d'activitat que té un alt rendiment pedagògic amb una inversió de temps $i$ organització reduïts i suposen també una oportunitat per al desenvolupament de les habilitats d'argumentació científica, molt presents en el currículum i que es poden treballar des d'un punt de vista lingüístic (Solbes et al, 2010, Trinidad, 2010).

Com a indicacions per a altres centres que vulguin dur a terme activitats similars, pensem que les següents indicacions poden ser d'utilitat:

- Compartir amb els alumnes l'objectiu de promoure la competència científica i explicitar les habilitats científiques que es volen treballar.

- Oferir als alumnes exemples i bastides lingüístiques de producció de gèneres comunicatius científics (pòsters, exposicions orals,...) i explicitar els rituals específics, com ara el ritual d'una sessió de pòsters (deambular per veure si algun pòster interessa, apropar-se, dedicar un moment a llegir-ne la informació, presentar-se a l'autor, ferli preguntes...).

- Okupar espais comuns del centre, amb produccions i investigacions que puguin ser comentades per professorat i alumnat més enllà de l'esdeveniment concret, i obrin vies de col•laboració.

- Assegurar la participació de tots els alumnes en la mesura de les seves possibilitats, adaptant si fa falta els formats o durada de les investigacions i promovent canvis en el seu rol de "receptors".

- Oferir un ampli rang de contexts i tipologies (pòster, taller, multimèdia,...) i nivells comunicatius (escrit, oral, gràfic,...) que permetin la identificació dels alumnes. 
- Emprendre estratègies de comunicació que evidenciïn la rellevància de la iniciativa, com convidar famílies, investigadors científics o institucions a assistir a l'activitat.

El lector interessat trobarà d'interès altres experiències o iniciatives similars (Moreno et al, 2014, Hinojosa, 2014, Díaz, 2013, Besson et al, 2015), recursos educatius relacionats com el projecte C3 (Creació del Coneixement Científic) [12] (Domènech-Casal, en edició), o programes institucionals, com el Fem Ciència, de la Universitat de Vic [13], el Congrés Juvenil sobre Evolució de Museu Blau de Barcelona [14], o el congrés científic que organitza la iniciativa La Ciència al Teu Món, de I'Institut de Biologia Evolutiva-CSIC [15].

\section{AGRAIIMENTS}

Els autors agraeixen la col-laboració de l'alumnat i professorat de l'INS Vilanova del Vallès. Reflexions incloses en aquest article s'emmarquen en la reflexió metodològica duta a terme en el grup LIEC (Llenguatge i Ensenyament de les Ciències) de la Universitat Autònoma de Barcelona, que forma part del grup de recerca consolidat LIEC (referència 2014SGR1492) per AGAUR (Agència de Gestió d'Ajuts Universitaris i de Recerca), finançat per el Ministerio de Economía y Competitividad (referència EDU2015-66643-C2-1-P).

\section{REFERÈNCIES}

AUTERI, S.M. (2015). All in the family. Building a hypothetical family portrait can help students to understand genetics. Science in school, 30, 2730.

BESSON, I., GOYTIA, E., MIRÓ, M., DOMĖNECHCASAL, J. (2015). Pràctiques mudes, congressos científics, seminaris de recerca $i$ altres dinàmiques científiques d'oralitat al laboratori i a l'aula. Ciències, en edició.

BYBEE, R.W. (2006). Scientific Inquiry and Science Teaching. A: L.B. Flick i N. G. Lederman (eds). Scientific inquiry and Nature of Science. Implicaitons for Teaching, Learning and Teacher Education. Dortrecht (The Nederlands) Springer.

CAAMAÑO, A. (2012). ¿Cómo introducir la indagación en el aula? Los trabajos prácticos investigativos. Alambique: didáctica de las ciencias experimentales, 70, 83-91.
CANALE, M. (1983). De la competencia comunicativa a la pedagogía comunicativa del lenguaje, pp 63-81 dins M. Llobera (ed) (1995), La competencia comunicativa. Barcelona, Edelsa.

DAWKINS, R. (1976). The selfish gene. Oxford: Oxford University Press.

DOMĖNECH-CASAL, J. (2013). Secuencias de apertura experimental y escritura de artículos en el laboratorio: un itinerario de mejora de los trabajos prácticos en el laboratorio. Enseñanza de las Ciencias 31 (3), 249-262.

DOMĖNECH-CASAL, J. (2014). Una secuencia didáctica en contexto sobre evolución, taxonomía y estratigrafía basada en la indagación y la comunicación científica. Alambique, Didáctica de las Ciencias Experimentales, 78, 51-59.

DOMÈNECH-CASAL, J. (en edició). Proyecto C3: indagación científica, lengua y contextos en la ESO. Aula de Secundaria, (acceptat).

DÍAZ, D. (2013). Mi primer congreso. Aula de Innovación Educativa, 223-224, 46-49.

GARRIDO, A., SIMARRO, C. (2014). El nou marc d'avaluació de la competència científica PISA 2015: Revisió i reflexions didàctiques. Ciències 28, 21-23.

HERNÁNDEZ, L., HERNÁNDEZ, C. (2011) . La expresión oral y escrita como proceso clave en el aprendizaje de las ciencias. Didáctica de las ciencias experimentales y sociales, $25,213-222$.

HINOJOSA, J. (2014). III Jornada del Treball de Recerca a l'Escola Pia Sarrià-Calassanç. Ciències, $28,30-32$.

HODSON, D. (1994). Hacia un enfoque más crítico del trabajo en el laboratorio. Enseñanza de las Ciencias, 12(3), 299-313.

LEMKE (1997). Aprender a hablar ciencia. Lenguaje, aprendizaje y valores. Barcelona: Paidós.

MARTíN, M. J. (2013). Hablar ciencia: si no lo puedo explicar, no lo entiendo. Revista eureka sobre Enseñanza y Divulgación de las Ciencias, 10 (3): 291-306.

MORENO, P.P., DELGADO, M.A., ABENZA, A.C. (2014). Un congreso científico en secundaria. 
Una experiencia para aprender y comunicar la ciencia. Aula de secundaria, 10, 20-24.

POZO, J. I., GÓMEZ, M.A. (2010). Por qué los alumnos no comprenden la ciencia que aprenden. Alambique, Didáctica de las Ciencias Experimentales, 73-79.

ROCARD, M., CSERMELY, P., JORDE, D., LENZEN, D., WALBERG-HERIKSSON, H., HEMMO, V. (2006). Science Education Now: a new pedagogy for the future of Europe. Report for the European Comission.

[http://ec.europa.eu/research/science-society/document_library/pdf_06/report-rocard-on-scienceeducation_en.pdf]

SANMARTÍ, N; IZQUIERDO, M; GARCÍA, P. (1999) Hablar y escribir: una condición para aprender ciencia. Cuadernos de Pedagogía, 281, 54-58.

SANMARTÍ N. (2008). Escribir para aprender ciencias. Aula de Innovación Educativa, 175, 29-32

SANMARTí, N., BURGOA, B., NUÑO, T. (2011) ¿Por qué el alumnado tiene dificultad para utilizar sus conocimientos científicos escolares en situaciones cotidianas? Alambique, Didáctica de las Ciencias Experimentales, 67, 62-69

SIMARRO, C., COUSO, D., PINTÓ, R. (2013). Indagació basada en la modelització: un marc per al treball pràctic. Ciències, 25, 35-43

SOLBES, J., RUIZ, J.J., FURIÓ, C. (2010) Debates y argumentación en las clases de física y química. Alambique, Didáctica de las Ciencias Experimentales , 63, 65-75.

TRINIDAD; O. (2010) Producción de argumentaciones escritas en las clases de física. Alambique, Didáctica de las Ciencias Experimentales, 63, 50-56.

\section{NOTES}

[1] Quan li corresponia, cada grup-classe s'ha dividit en dos subgrups. Durant la primera mitja hora un subgrup assistia a l'exposició de l'altre nivell, i en paral•lel l'altre subgrup presentava els seus pòsters a la pròpia aula. La segona mitja hora es canviaven els papers
[2] Es defineix com a meme una unitat d'informació cultural. Els memes serien els equivalents culturals a la informació biològica, els gens, i estarien subjectes a dinàmiques similars de mutació i selecció (Dawkins, 1976).

[3] Webquest Heredity ld: https://sites.google.com/site/heredityid/home

[4] Aplicació de Recursos al Currículum (ARC) http://apliense.xtec.cat/arc/node/30189

[5] La bastida és disponible a la pàgina web del Projecte C3: https://sites.google.com/a/xtec.cat/c3/activitatsde-comunicacio-cientifica/posters-cientifics

[6] Myths of human genetics http://udel.edu/ mcdonald/mythintro.html

[7] Un exemple d'una de les produccions dels alumnes mitjançant Prezi: https://prezi.com/refrhu19n7bq/la-cristalitzacio/

[8] En alguns casos, l'oxidació del metall del clip provocava taques grogues en els cristalls.

[9] Descàrrega de la pràctica Pràctica 2: Extracció de clorofil-la:

https://app.box.com/s/0lc6h8gf1j5s7a9flqksf383 o08s0b9k

[10] Activitat Context-Taxon, disponible per a la seva descàrrega: https://blogcienciesnaturals.wordpress.com/2014/12/29/con-tex-tax-onclassificacio-i-claus-dicotomiques/

[11] PepQuímic, ciència quotidina per a la vida quotidiana:

https://pepqui-

mic.wordpress.com/2011/06/30/experiments-deciencia-recreativa-al-curs-destiu-quimica-a-labast/

[12] https://sites.google.com/a/xtec.cat/c3/home

[13] http://mon.uvic.cat/femciencia/

[14]https://storify.com/museuciencies/i-congres-juvenil-sobre-evolucio-al-museu-blau

[15] http://lacienciaalteumon.cat/inici-3/ 